\title{
KAJIAN NORMATIF DAN EMPIRIS UNDANG-UNDANG NOMOR 39 TAHUN 1999 TENTANG HAK ASASI MANUSIA KHUSUSNYA HAM EKOSOSB (EKONOMI, SOSIAL, BUDAYA) DAN HAK-HAK ATAS LINGKUNGAN
}

\author{
Helen Sondang Silvina Sihaloho \\ Kantor Wilayah Kementerianhukum Dan Ham Riau \\ Email :helensilvina88@gmail.com
}

\begin{abstract}
Basically, all this time, environmental management has been understood as the task of the state. This means that it is the state that is responsilble for managing the collective behavior of mankind through the policies it takes. It is not surprising that we are accustomed to relying on use of state authorities in regulating environmental management. In fact, the work of the government bureaucracy make one institution easily shift its responsibilities to other institutions. The work of the government bureaucracy which is expected to ensure the management of environmental problems, actually creates environmental problems it self. National legal policy stiil place the recognition and protection of Ecosob and Social Rights rights as rights that are not prioritized because of yhe assumption that Indonesia is still in the category of developing countries,so it is very natural that citizens economic and social rights rights are still not maximized.
\end{abstract}

Keywords: Normative Study, Human Rights, Rights to the Environment.

\begin{abstract}
Abstrak
Pada dasarnya, selama ini pengelolaan lingkungan itu difahami sebagai tugas negara. Artinya, negaralah yang bertanggung jawab mengelola perilaku kolektif umat manusia melalui kebijakan-kebijakan yang diambilnya. Tidaklah mengherankan kalau kita kemudian terbiasa menggantungkan diri pada penggunaan otoritas negara dalam meregulasi pengelolaan lingkungan hidup. Justru bekerjanya birokrasi pemerintahan menjadikan lembaga yang satu dengan mudahnya melempar tanggung jawabnya ke pada lembaga lain. Bekerjanya birokrasi pemerintahan, yang diharapkan akan memastikan terkelolanya persoalan lingkungan hidup, justru menciptakan masalah lingkungan itu sendiri. Kebijakan hukum nasional masih menempatkan pengakuan dan perlindungan hak Ekosob sebagai hak yang tidak diprioritaskan karena aadanya anggapan bahwa Indonesia masih masuk kategori negara berkembang sehingga sangat wajar jika hak Ekosob warga negara masih belum maksimal.

Kata Kunci: Kajian Normatif, Hak Asasi manusia, Hak Atas Lingkungan
\end{abstract}




\section{Pendahuluan}

Undang-undang dasar 1945 sebagai landasan konstribusional menegaskan bahwa sumber daya alam agar dipergunakan untuk sebesarbesarnya bagi kemakmuran rakyat dan harus dapat dinikmati baik oleh generasi sekarang maupun generasi mendatang. Kebijakan nasional sebagaimana ditetapkan Garis-garis Besar Haluan Negara (GBHN) telah menggariskan bahwa pembangunan nasional merupakan pembangunan berwawasan lingkungan dan bahwasanya salah satu tujuan akhir pembangunan Nasional adalah tercapainya keselarasan hubungan manusia dengan lingkungan alam sekitarnya. Sebagai landasan operasional GBHN lebih lanjut memberikan arah bahwa pelaksanaan pembangunan harus selalu diusahakan untuk memelihara kelestarian kemampuan lingkungan, mencegah pencemaran dan kerusakan lingkungan hidup serta mencegah pemborosan penggunaan sumber alam. Lingkungan hidup merupakan isu terpenting dalam kehidupan manusia. ${ }^{1}$

Indonesia sebagai negara yang heterogen yang terdiri dari multi etnis, multi agama, dan multi kultur pada satu sisi menjadi kebanggaan tersendiri sebagai sebuah bangsa yang besar, akan tetapi jika tidak dikelola secara baik dengan menegakkan prinsip toleransi, saling menghormati dan saling menghargai, adanya perbedaan justru akan menjadi malapetaka bagi bangsa ini.

\section{Kajian Pustaka}

Hak asasi merupakan hak dasar seluruh umat manusia tanpa ada perbedaan. Mengingat hak dasar merupakan anugerah dari Tuhan Yang Maha Esa, maka pengertian hak asasi manusia adalah hak segala anugrah Tuhan Yang Maha Esa yang melekat pada setiap diri manusia, bersifat kodrati universal dan abadi yang terkait dengan harkat dan martabat manusia.Setiap manusia diakui dan dihormati mempunyai hak

\footnotetext{
${ }^{1}$ Majda El Muhtaj,'Dimensi-Dimensi HAM mengurai hak ekonomi,sosial dan budaya",PT Grafindo Persada,2009,hal 192.
} 

Helen

asasi yang sama tanpa membedakan jenis kelamin, warna kulit, kebangsaan, agama, usia, pandangan, politik, status sosial dan bahasa serta status lain pengambilan atau perampasannya mengakibatkan hilangnya harkat dan martabat manusia.Bangsa Indonesia menyadari bahwa hak asasi manusia bersifat historis dan dinamis yang pelaksanaannya berkembang dalam kehidupan bermasyarakat berbangsa dan benegara.

Pada pasal 3 Undang-Undang No 39 tahun 1999 tentang Hak Azazi Manusia menyatakan :

"Setiap orang dilahirkan bebas dengan harkat dan martabat manusia yang sama dan sederajat serta dikaruniai akal dan hati nurani untuk hidup bermasyarakat, berbangsa, dan bernegara dalam semangat persaudara-an.Setiap orang berhak atas pengakuan, jaminan, perlindungan dan perlakuan hukum yang adil serta mendapat kepastian hukum dan perlakuan yang sama di depan hukum. Setiap orang berhak atasperlindungan hak asasi manusia dan kebebasan dasar manusia, tanpa diskriminasi" . "Tidak seorang pun boleh diperbudak atau diperhamba. Perbudakan atau perhambaan,".

Pasal 20, Undang-undang No. 39 Tahun1999 tentang Hak asasi Manusia

"Pedagangan budak, perdagangan wanita, dan segala perbuatan berupa apapun yang tujuannya serupa, dilarang".

Pasal 65, Undang-undang No. 39 Tahun1999 tentang Hak asasi Manusia

"Setiap anak berhak untuk memperoleh perlindungan dari kegiatan eksploitasi dan pelecehan seksual, penculikan, perdagangan anak, serta dari berbagai bentuk penyalahgunaan narkotika,psikotropika, dan zat adiktif lainnya."

Hak merupakan unsur normatif yang melekat pada diri setiap manusia yang dalam penerapannya berada pada ruang lingkup hak persamaan dan hak kebebasan yang terkait dengan interaksinya antara individu atau dengan instansi. Hak juga merupakan sesuatu yang harus diperoleh. Masalah HAM adalah sesuatu hal yang sering kali dibicarakan 

Helen

dan dibahas terutama dalam era reformasi ini. HAM lebih dijunjung tinggi dan lebih diperhatikan dalam era reformasi dari pada era sebelum reformasi.Dalam hal pemenuhan hak, kita hidup tidak sendiri dan kita hidup bersosialisasi dengan orang

\section{Metode Penelitian}

Agar didalam penelitian dapat diperoleh hasil sebagaimana yang diharapkan sesuai dengan masalah pokok yang sudah dirumuskan,maka penulis menyusun Penelitian ini dilakukan dengan menggunakan jenis penelitian hukum normatif dalam bentuk studi dokumen antara lain :

1. Undang-Undang No 39 tahun 1999 tentang Hak Azazi Manusia, UU No. 32 Tahun 2009 tentang Perlindungan serta Pengelolaan Lingkungan Hidup dan PP No 27 tahun 1999 tentang Analisis Mengenai Dampak Lingkungan Hidup (AMDAL)

2. Artikel dari media cetak / internet

3. Studi Kepustakaan.

Sedangkan jika dilihat dari sifatnya maka penelitian ini bersifat deskriptif analitis ,maksudnya penelitian yang memberikan data seteliti mungkin tentang manusia,keadaan dan gejala - gejala lainnya,dengan maksud mempertegas hipotesa,untuk memperkuat teori-teori lama atau menyusun teori-teori baru. ${ }^{2}$

\section{Hasil Penelitin dan Pembahasan}

\section{Pengaturan HAM di Indonesia.}

Pengaturan Hak Asasi Manusia terdapat pada Undang-Undang No 39 tahun 1999 tentang Hak Azazi Manusia .Dalam perundang-undangan RI paling tidak terdapat bentuk hukum tertulis yang memuat aturan tentang HAM. Pertama, dalam konstitusi (UUD Negara). Kedua, dalam ketetapan MPR (TAP MPR). Ketiga, dalam Undang-undang. Keempat, dalam peraturan pelaksanaan perundang-undangan seperti peraturan pemerintah, keputusan presiden dan peraturan pelaksanaan lainnya.

\footnotetext{
${ }^{2}$ Soerjono Soekanto, Pengantar Penelitian Hukum,UI Press,Jakarta,2007,hlm.10.
} 

Helen

Undang-Undang dasar 1945,di tegaskan bahwa Negara Republik Indonjesia adalah suatu Negara Hukum .Hal itu berarti bahwa Negara Republik Indonesia :

1. Menjunjung tinggi hak asasi manusia dan menjamin segala warga negaranya bersamaan kedudukannya di dalam hokum dan pemerintahan serta wajib menjunjung tinggi hokum dan pemerintahan itu dengan tidak ada kecualinya.

2. Menjunjung tinggi azaz peradilan yangt bebas ,dalam arti tidak tunduk kepada kekuasaan laimn yang manapun. ${ }^{3}$

Tanggung jawab pemajuan, penghormatan dan perlindungan HAM tidak saja dibebankan kepada negara, melainkan juga kepada individu warga negara. Artinya negara dan individu sama-sama memiliki tanggung jawab terhadap pemajuan, penghormatan dan perlindungan HAM. Karena itu, pelanggaran HAM sebenarnya tidak saja dilakukan oleh negara kepada rakyatnya, melainkan juga oleh rakyat kepada rakyat yang disebut dengan pelanggaran HAM secara horizontal.

\section{Perbedaan Mekanisme Penyelesaian Pelanggaran HAM Sipil dan Ham Ekosob.}

Tanggung jawab pemajuan, penghormatan dan perlindungan HAM tidak saja dibebankan kepada negara, melainkan juga kepada individu warga negara. Artinya negara dan individu sama-sama memiliki tanggung jawab terhadap pemajuan, penghormatan dan perlindungan HAM. Karena itu, pelanggaran HAM sebenarnya tidak saja dilakukan oleh negara kepada rakyatnya, melainkan juga oleh rakyat kepada rakyat yang disebut dengan pelanggaran HAM secara horizontal.

Hak asasi manusia internasional merupakan kesempatan yang baik bagi Indonesia untuk memperbaiki hak asasi manusia yang buruk. Hal ini tidak dapat diselesaikan dengan ratifikasi saja, tetapi juga harus diikuti

\footnotetext{
3 R.Subekti,Perlindungan hakasasi manusia Dalam KUHAP,PT Pradnya Paramita,Jakarta, hlm 4.
} 

Helen

dengan implementasi. Institusi peradilan Indonesia -kepolisian, kejaksaan, dan kehakiman- semua dalam keadaan bobrok, tidak mampu menegakkan hukum dan melindungi hak-hak warga negara. Penyiksaan dan kekerasan selama penahanan adalah praktek yang umum di kantor kepolisian Indonesia. Kejaksaan Agung Indonesia terus dimotivasi oleh faktor politik dan jarang melakukan proses hukum terhadap pelaku kejahatan dan pelanggaran HAM. Masalah kunci dalam sistem peradilan Indonesia adalah korupsi, yang diikuti dengan pembebasan pelaku kejahatan.

Dalam keadaan ini, Indonesia punya tugas berat untuk memenuhi hak-hak warga negaranya. Dalam mereformasi institusi peradilannya, semua elemen korupsi harus dihapuskan dan semua pejabat harus bisa dimintai pertanggungjawaban atas tindakan mereka. Secara khusus, semua tiga institusi harus menghormati setinggi-tingginya supremasi hukum dan persamaan hak di depan hukum. Pemerintah Indonesia harus mengambil semua langkah untuk menjamin setiap orang untuk tidak merasa terancam dalam menyatakan pendapatnya, sebagaimana yang terjadi pada kasus terbunuhnya pembela HAM, Munir Said Thalib. setiap hak yang terkait dengan warga negara dengan sendiri bertimbal-balik dengan kewajiban negara untuk memenuhinya.

Demikian pula dengan kewenangan-kewenangan konstitusional yang dimiliki oleh negara melalui organ-organnya juga bertimbal-balik dengan kewajiban-kewajiban konstitusional yang wajib ditaati dan dipenuhi oleh setiap warga negara. Pelanggaran hak asasi manusia didefinisikan sebagai suatu pelanggaran terhadap kewajiban negara yang lahir dari instrumen-instrumen internasional hak asasi manusia. Akhir-akhir ini terlihat terjadi tindak pindana kekerasan dari kelompok tertentu terhadap kelompok yang lain, selain karena tidak ada toleransi dan saling menghormati, juga karena perbedaan pemahaman dan penafsiran terhadap ajaran agama, karena merasa diri paling benar dan berkuasa. Tindakan "main hakim" sendiri seperti itu sangat bertentangan dengan 

Helen

semangat yang tertuang dalam Pembukaan Konstitusi 1945 dan instrumen internasional yang telah diadopsi. Penegakan hukum dan pembenahan hukum yang mendukung penegakan hokum juga diartikan sebagai menyesuaikan atau mengharmonisasikan peraturan perundang-undangan yang telah mengatur mengenai HAM, mulai dari tingkat undang-undang hingga peraturan di bawah nya.

\section{Kewajiban Negara dalam Menghormati,Memenuhi,Memajukan dan Melindungi Hak-Hak Asasi Manusia,Khususnya HAM Ekososb dan Hak-Hak Atas Lingkungan.}

Upaya untuk menumbuhkan kesadaran hukum masyarakat dalam pelestarian lingkungan dapat dilakukan dengan beberapa cara, yaitu : Pertama, meningkatkan program sosialisasi dari tingkat pusat sampai ke desa-desa, khususnya berkaitan dengan hak dan kewajiban serta berbagai permasalahan riil yang dihadapi oleh masyarakat, seperti prosedur AMDAL, perizinan dan dampak positif dan negatif apabila prosedur tersebut tidak dilakukan. Kedua, meningkatkan kesadaran hukum (mental) semua pihak. Ketiga, menindak tegas oknum pemerintah/aparat yang menyalahgunakan wewenangnya dan menindak tegas pelaku perusakan/pencemaran lingkungan tanpa tebang pilih sehingga masyarakat percaya dengan upaya penegakan hukum lingkungan. Keempat, memangkas proses birokrasi yang panjang dan berbelit-belit. Berbicara tentang Hak Asasi Manusia, berarti berbicara tentang hak manusia yang paling dasar dan fundamental. Setiap manusia di muka bumi berhak atas hak ini dan dimanapun tempat mereka tinggal seharusnya Hak Asasi Manusia harus dijunjung tinggi.

Adapun yang menjadi kewajiban negara dalam melindungi hak-hak manusia dalam HAM Ekosob dan hak-hak atas lingkungan seperti:

1. Negara Indonesia mengakui bahwa manusia, sebagai makhluk ciptaan Tuhan Yang Maha Esa yang mengelola dan memelihara alam semesta dengan penuh ketaqwaan dan penuh tanggung 

Helen

jawab untuk kesejahteraan umat manusia, oleh pencipta-Nya dianugerahi hak asasi untuk menjamin keberadaan harkat dan mertabat kemuliaan dirinya serta keharmonisan lingkungannya.

2. Negara Indonesia mengakui bahwa hak asasi manusia merupakan hak dasar yang secara kodrati melekat pada diri manusia, bersifat universal dan langgeng, oleh karena itu harus dilindungi, dihormati, dipertahankan, dan tidak boleh diabaikan, dikurangi, atau dirampas oleh siapa pun.

3. Negara Indonesia mengakui bahwa selain hak asasi, manusia juga mempunyai kewajiban dasar antara manusia yang satu terhadap yang lain dan terhadap masyarakat secara keseluruhan dalam kehidupan bermasyarakat, berbangsa, dan bernegara.

4. Negara Indonesia sebagai anggota Perserikatan bangsa-bangsa mengemban tanggung jawab moral dan hukum untuk menjunjung tinggi dan melaksanakan berbagai instrumen Internasional lainnya mengenai Hak Asasi Manusia yang telah diterima oleh Negara RepublikIndonesia

Pandangan dan kepribadian bangsa Indonesia yang merupakan kristalisasi nilai-nilai luhur bangsa Indonesia, telah menempatkan manusia pada keluhuran harkat dan martabat makhluk Tuhan Yang Maha Esa dengan kesadaran mengemban kodratnya sebagai makhluk pribadi dan juga makhluk sosial, tertuang dalam Pembukaan Undang-Undang Dasar 1945. Nilai-nilai luhur bangsa Indonesia sebagai satu kesatuan yang utuh dan bulat itulah yang dirumuskan menjadi dasar negara.

Hak Asasi Manusia ini tidak bisa seragam dan sama di setiap negara, tetapi setiap negara setidaknya mempunyai pikiran ideal yang sama mengenai Hak Asas Manusia ini. Manusia sebagai pribadi maupun sebagai rakyat/ warga negara, dalam mengembangkan diri, berperan dan memberikan sumbangan dalam kehidupan, ditentukan oleh pandangan hidupnya sesuai dengan kepribadian bangsa. Bagi individu dimasyarakat, misalnya dengan tidak membuang sampah sembarangan. Bagi pelaku 

Helen

usaha, misalnya melakukan AMDAL dan pengelolaan limbah yang dihasilkan. Sementara bagi Pemerintah, misalnya dengan memperketat proses AMDAL dan perizinan, serta menindak tegas pegawai yang menyalahgunakan kewenangannya, seperti memberikan AMDAL dan izin tanpa prosedur yang seharusnya. Selain itu, pemerintah dalam membuat kebijakan tata kota dan perizinan area bisnis hendaknya memperhatikan kondisi lingkungan tidak hanya untuk saat ini tetapi juga untuk masa yang akan datang.

Kewajiban-kewajiban asasi warga negara,dalam HAM Ekososb.

Dalam kaitannya dengan HAM Ekososb warga negara berkewajiban :

1. Warga Negara wajib melestarikan kebudayan yang menjadi ciri khas bangsa indonesia.

2. Warga Negara wajib membantu pengembangan ekonomi dan pembangunan bangsa indonesia dengan melakukan kewajibannya terhadap negara yakni seperti mebayar pajak.

3. Warga negara wajib menghormati hak asasi manusia orang lain,dan tertib dalam kehidupan bermasyarakat,berbangsa dan bernegara.

Oleh karena itulah adanya hak dan kewajiban yang seimbang yang harus di patuhi dan silaksanakan demi kelancaran pembangunan di Indonesia karena posisi Indonesia yang masihtergolang negara berkembang hingga saat ini.Sebagai warga negara yang baik sudah tentu kita tidak bisa mengingkari kewajiban kita terhadap negara.Mengingat banyaknya masalah yang mengenai HAM yang sedang mareaknya di Indonesia.

\section{Peranan Negara Baik Secara Aktif Maupun Pasif dalam Memenuhi,Menghormati dan Melindungi HAM Ekosob,Khususnya Hak Atas Lingkungan.}

Pengelolaan lingkungan hidup adalah upaya terpadu untuk melestarikan fungsi lingkungan hidup yang meliputi kebijaksanaan 

Helen

penataan, pemanfaatan, pengembangan, pemeliharaan, pemulihan, pengawasan, dan pengendalian lingkungan hidup. Sumber daya alam seperti air, udara, tanah, hutan dan lainnya merupakan sumberdaya yang penting bagi kelangsungan hidup mahkluk hidup termasuk manusia. Bahkan, SDA ini tidak hanya mencukupi kebutuhan hidup manusia, tetapi juga dapat memberikan kontribusi besar terhadap kesejahteraan yang lebih luas. Namun, semua itu bergantung pada bagaimana pengelolaan SDA tersebut, karena pengelolaan yang buruk berdampak pada kerugian yang akan ditimbulkan dari keberadaan SDA, misalnya dalam bentuk banjir, pencemaran air, dan sebagainya.

Demikian pula dengan warga negara juga tidak bisa melanggar hukum dan Hak Asasi Manusia. Upaya pemajuan dan pelindungan HakHak Asasi Manusia ternyata tidak semudah membalikan telapak tangan. Upaya tersebut tidak dapat dilakukan dalam waktu sekejap, akan tetapi memerlukan suatu proses yang panjang. Karena itu, upaya tersebut perlu dilakukan secara terus menerus, berkelanjutan, dan terpadu. Semua pihak, yakni pemerintah, organisasi-organisasi sosial politik dan kemasyarakatan, maupun berbagai lembaga-lembaga swadaya masyarakat, serta semua kalangan dan lapisan masyarakat dan warga negara perlu terlibat dalam penegakan Hak Asasi Manusia di Indonesia. Upaya-upaya yang telah dilakukan oleh pemerintah dalam rangka menegakan Hak Asasi Manusia

Pandangan yang selama ini telah difahami adalah bahwa, supaya manusia bisa mendapatkan manfaat yang optimal, maka lingkungan hidup harus dikelola. Dalam hal ini, manusia memperlakukan dirinya sebagai subyek dan lingkungan hidup sebagai obyek manajemen. Tersirat di sini, lingkungan hidup yang diatur dan di tata sedemikian rupa sehingga manusia tidak sengsara, umat manusia bisa sejahtera. Pertanyaan yang perlu kita renungkan sekarang: bisakah lingkungan hidup terus-menerus di eksplorasi sistem kerjanya agar upaya untuk meningkatkan kesejahteraannya tidak terganggu ?. Semakin terorganisir suatu tatanan 

Helen

sosial, semakin sistemik masyarakat tersebut mengubah alam dan efek yang ditimbulkan juga semakin kompleks.HAM atas lingkungan hidup merupakan hak fundamental manusia. ${ }^{4}$

Dalam penegakan hukum lingkungan yang efektif saharusnya memiliki kendala seperti perbedaan persepsi dan rendahnya koordinasi di antara aparat penegak hukum terkait, lemahnya pengetahuan teknis dan integritas aparat penegak hukum (judicial corruption), keterbatasan kapasitas budget dan ketiadaan akses informasi dan partisipasi yang menyebabkan kontrol eksternal menjadi tidak efektif.penegakan hukum lingkungan saat ini berada pada posisi stagnasi yang berkelamaan, buruknya implementasi dari aturan yang diterbitkan, serta hanya sekedar mengutamakan instrument command,and,control.Penegakan hukum lingkungan hanya sebagai tools yang bertujuan akhir sebuah compliance.

Kondisi saat ini menunjukkan bahwa regulasi yang ada hanya kaya akan jumlah namun miskin dengan penataan.Mengingat adanya kecenderungan umum yang dipaparkan di atas tersirat bahwa manajemen lingkungan dikembangkan dengan penghayatan yang sangat tipis, dan sebagai konsekuensinya, tidaklah mengherankan kalau kerusakan lingkungan hampir-hampir tidak terkendali. Ancaman terjadinya krisis lingkungan kini harus diterima. Perlu di catat, krisis lingkungan tidak akan pernah bisa dibatasi lingkupannya sekedar sebagai krisis lingkungan semata. Krisis lingkungan akan memicu krisis sosial. Dalam berbagai manifestasi dan skala, kita telah lama mengetahui bahwa kerusakan lingkungan akan berbuntut kerusakan tatanan sosial.

Menggejalanya kerusakan lingkungan senantiasa menyeret konflik lingkungan hidup kini semakin merajalela. Sebaliknya, konflik sosial yang terjadi tidak jarang justru memicu penggunaan sumberdaya alam dan pada gilirannya menghasilkan konflik sosial yang baru, atau konflik yang berskala lebih luas. Bagi para fihak yang berperang, kemenangan adalah difahami sebagai hal yang paling esensial. Tapi, siapapun yang menang,

${ }^{4}$ Ibid,hlm.204 

Helen

masing-masing harus menanggung kerugian ekologis: merelakan kerusakan lingkungan.

Secara aktif negara dapat melakukan serangkaian advokasi kebijakan agar negara memiliki organ khusus yang memilikirkan dan menangani persoalan-persoalan lingkungan yang mengedepan. Di Indonesia, hal ini ditandai dengan pembentukan Kementerian Pengawasan Pembangunan dan Lingkungan Hidup, yang belakangan ini berubah menjadi Kementerian Lingkungan Hidup. Adanya lembaga yang secara khusus memikirkan lingkungan hidup ini telah memungkinkan terjadinya replikasi pendekatan managerialistik dalam setiap organ pemerintahan. Managemen lingkungan hidup ditumbuhkembangkan si setiap sektor birokrasi pemerintahan.

Sungai merupakan salah satu ekosistem perairan terbuka yang mengalir dari bagian hulu hingga ke hilir. Badan sungai, bantaran dan daerah tangkapan air sepanjang daerah aliran sungai (DAS) tersebut kualitasnya dapat dipengaruhi oleh kondisi lingkungan sekitarnya. Sungai sebagai sebuah ekosistem memiliki daya homeotasis yaitu suatu kemampuan untuk menahan berbagai jenis perubahan untuk mempertahankan keseimbangannya. Mekanisme mempertahankan daya keseimbangan tersebut meliputi pengaturan penyimpanan material, terjadinya aliran antara komponen, terjadinya interaksi inter dan antar populasi, pelepasan hara makanan, perkembangan dan pertumbuhan organisme, produksi, serta dekomposisi bahan organik. UU No. 32 Tahun 2009 tentang Perlindungan serta Pengelolaan Lingkungan Hidup berisikan upaya sistematis dan terpadu untuk melestarikan lingkungan serta sebagai upaya pencegahan terjadinya pencemaran dan atau kerusakan lingkungan hidup.

Sedangkan secara pasif justru kalau ummat manusia mengikuti hukum-hukum alam.kalkukasi rasional-irrasional dalam cara pandang ekosentrik ini tidaklah dari kaca mata individual, melainkan dari kacamata kolektif. Unit yang dianalisis tidak hanya manusia dengan segala 

Helen

kepentingannya, melainkan ekosistem dunia dengan manusia sebagai salah satu komponennya. Lingkungan hidup yang bersih dan sehat merupakan gerbang kedepan mmbangun koeksistensi manusia dengan alam dan begitu juga sebaliknya. ${ }^{5}$ Perlu diingat, kegagalan birokrasi pemerintah dalam menyelenggarakan skema-skema manajemen lingkungan adalah karena tidak adanya komitmen terhadap nilai-nilai ekologis. Birokrasi pemerintahan tidak bisa diandalkan untuk diperankan sebagai instrumen pengelolaan lingkungan hidup karena sistem nilai yang ada di dalam birokrasi pemerintahan tersebut tidak sensitif terhadap premis-premis ekologis. Berfungsinya ekosistem tidak pernah mengenal yurisdiksi spasial para pejabat negara, dan mereka tetap saja bersiteguh dengan pemilahan fungsi secara spasial. Ekosistem tidak mengenal batas-batas kewenangan sektoral.

\section{Contoh-Contoh /Fakta-Fakta atas di penuhinya HAM Ekososb dan Atas diabaikannya pelanggaran HAM Ekosob,Khususnya Hak Atas Lingkungan.}

Di Indonesia Analisis Mengenai Dampak Lingkungan Hidup (AMDAL) diatur dalam PP No 27 tahun 1999. AMDAL adalah kajian mengenai dampak besar dan penting suatu usaha dan/atau kegiatan yang direncanakan pada lingkungan hidup. AMDAL sangat diperlukan bagi proses pengambilan keputusan tentang penyelenggaraan usaha dan/atau kegiatanyang dinilai berpotensi berdampak negatif terhadap lingkungan. AMDAL sebagai salah satu instrumen proses penegakkan hukum administrasi lingkungan belum terlaksana sebagaimana mestinya. Padahal pada instrumen ini dilekatkan suatu misi mengenai kebijakan pembangunan berkelanjutan dan berwawasanlingkungan.

Mochtar Kusumaatmadja mengemukakan,bahwa system pendekatan terpadu, atau utuh menyeluruh harus di terapkan oleh hokum

${ }^{5}$ Ibid,hal 201. 

Helen

untuk mampu mengatur lingkungan hidup manusia secara tepat dan baik. ${ }^{6}$ Untuk memenuhi kewajiban dan tanggung jawab Pemerintah Daerah dalam mewujudkan kesejahteraan rakyat di Daerah maka seluruh potensi sumber daya yang tersedia di Daerah akan dimanfaatkan seoptimal mungkin. Salah satu potensi sumber daya yang dimiliki Sebagian Daerah adalah potensi daerah sungai.

Masalah-masalah yang belum terakomodasi oleh ketentuanketentuan yang dianggap mengandung kelemahan-kelemahan tertentu, seperti keterkaitan AMDAL denga perizinan, mekanisme keterkaitan AMDAL dan masyarakat sebagai pelaksana peran serta rakyat dalam proses pengambilan keputusan, dan metode pengumpulan informasi yang mampu memberikan identifikasi terhadap berbagai pengaruh dan dampak lingkungan. Ini berarti dalam hal perencanaan proyek pusat, komisi daerah telah dilibatkan, yang akan menjamin keterpaduan vertical. Oleh karena itu, penguasaan hukum yang mengatur dan menerbitkan masalah lingkungan dalam pembangunan wajib kita menguasai pula ilmu-ilmu lain yang relevan, misalnya ekonomi, sosial budaya, planologi, hidrologi, kimia dan biologi. Pendekatan interdisipliner ilmu demikian dapat dan berkembang. Meningkatkan kegiatan pembangunan, akan membawa perkembangan baru atas pengertian bahaya, kerugian daan lingkungan tercemar terhadap aspek kesehatan dan lingkunga salah satu "Instrumen Hukum" yang dikembangkan dan mengatasi ini adalah AMDAL.

Dengan demikian, dalam perkembangan baru ini, hokum disamping untuk menjaga ketertiban, sarana pembaharuan masyarakat juga dianggap mampu mengidentifikasi dan menginterpretasikan masalahmasalah lingkunga yang mungkin timbul daaan tata cara memecahkannya. Suatu perkembangan hukum yang dipengaruhinya oleh metode dan prinsip ilmu.Untuk melakukan analisis secara demikian, Undang-undang Lingkungan Hidup Tahun 1982 dan peraturan Pemerintah

${ }^{6}$ Koesnadi Hardjasoemantri, Hukum Tata Lingkungan,Gadjah Mada University Press, Yogyakarta,hlm.15. 

Helen

tentaang AMDAL akan dijadikan acuan utama dalam keseluruhan proses pengujiaan masalah dan sarana pemecahaannya. Atas dasar pemikiran diatas, analisis masalah hukum tentang AMDAL pertama-tama akan membantu memberikan uraian keterkaitan perundangundangan dan pelaksanaan AMDAL dengan Undang-undang atau ketentuan hokum sektoral untuk memperoleh persamaan persepsi dan penafsiran atas hokum yang mengatur pelaksanaan AMDAL dilihat dari penyusunan, penilaian, dan pengambilan keputusan. Kedua, pengaruh dari kualifikasi AMDAL oleh perangkat aparatur pemerintah yang memiliki criteria keahlian khusus dalam proses AMDAL sebagai penanggung jawab utama. Hukum perlindungan lingkungan tidak menegani satu bentuk kebijaksanaan ,akan tetapi merupakan kumpulan dari berbagai peraturan perundang-undangan di bidang pengelolaan lingkungan biotis dan sampai batas tertentu dengan lingkungan antropogen. ${ }^{7}$

Mengenai masalah analisis mengenai dampak lingkungan adalah menyangkut masalah orang banyak, maka peranan pihak yang berkepentingan yaitu pemrakarsa, aparatur pemerintah, dan masyarakat sangat penting. Oleh karena itu untuk menegakkan analisis mengenai dampak lingkungan ini harus ada kerjasama yang baik antara aparatur pemerintah dan pihak yang terkait.Untuk itu Menteri Negara Kependudukan dan Lingkungan Hidup telah mengeluarkan beberapa keputusan sebagai realisasi dari pelaksanaan Peraturan Pemerintah No. 27 Tahun 1999 yang isinya merupakan pedoman bagi para konsultan yang akan membuat analisis mengenai dampak lingkungan. Oleh karena itu seorang konsultan tidak boleh menyimpang dari ketentuan diatas.

UU No. 32 Tahun 2009 tentang Perlindungan serta Pengelolaan Lingkungan Hidup juga menggunakan asas kerja sama (cooperation principle) dalam upaya preventif terhadap terjadinya kerusakan lingkungan yang tercantum pada pasal 1 ayat (2) yang berbunyi: "Perlindungan dan pengelolaan lingkungan hidup adalah upaya sistematis dan terpadu yang

\footnotetext{
${ }^{7}$ Ibid,hlm. 15.
} 

Helen

dilakukan untuk melestarikan fungsi lingkungan hidup dan mencegah terjadinya pencemaran dan/atau kerusakan lingkungan hidup yang meliputi perencanaan,pemanfaatan, pengendalian, pemeliharaan,pengawasan,peneg akan hukum".

Berdasarkan ketentuan diatas pelanggar dapat diperingati agar berbuat sesuai izin dan apabila tidak, akan dikenakan sanksi yang paling keras pencabutan izin usaha perusahaan pengalengan ikan yang terbukti membuang limbah ke pesisir Kepala Daerah dapat mengajukan usul untuk mencabut izin usaha dan/atau kegiatan kepada pejabat yang berwenang. Selain itu pihak yang berkepentingan dapat mengajukan permohonan kepada pejabat yang berwenang untuk mencabut izin usaha dan/atau kegiatan karena merugikan kepentingannya. Upaya adminisrtatif adalah upaya tercepat karena tidak memerlukan proses peradilan. Dalam kasus pengerusakan lingkungan upaya ini terasa lebih relevan mengingat pencemaran lingkungan hidup memerlukan upaya yang cepat agar kerugian yang ditimbulkan tidak terus bertambah.

\section{Kesimpulan}

Di dalam perlindungan hak-hak sipil dan politik, peran negara harus dibatasi karena hak-hak sipil dan politik tergolong ke dalam negative right, yaitu hak-hak-hak dan kebebasan yang dijamin di dalamnya akan terpenuhi apabila peran negara dibatasi. sejarah pelanggaran HAM yang terutama dilakukan oleh negara, baik terhadap hak sipil-politik maupun hak ekonomi, sosial, dan budaya. Sebagai konsekuensinya, disamping karena sudah merupakan tugas pemerintahan, kewajiban utama perlindungan dan pemajuan HAM ada pada pemerintah.

Masalah-masalah yang belum terakomodasi oleh ketentuanketentuan yang dianggap mengandung kelemahan-kelemahan tertentu, seperti keterkaitan AMDAL denga perizinan, mekanisme keterkaitan AMDAL dan masyarakat sebagai pelaksana peran serta rakyat dalam proses pengambilan keputusan, dan metode pengumpulan informasi yang 

Helen

mampu memberikan identifikasi terhadap berbagai pengaruh dan dampak lingkungan. salah satu instrumen hukum yang berperan tentang penegakkan hukum lingkungan adalah hukum administrasi. Instrumen hukum administratif berbeda dengan instrumen lainnya, oleh karena penyelesaiannya adalah di luar lembaga peradilan.

Kecenderungan manusia melanggar kesepakatan atau aturan hukum itu selain terhadap dirinya sendiri, juga terjadi terhadap kehidupan diliuar dirinya, seperti terhadap sumber daya lingkungan, khususnya terumbu karang. Disisi lain, sanksi memiliki kelemahan, karena biasanya sanksi itu ada setelah terjadinya peristiwa. Itulah sebabnya mengapa tindakan pecegahan lebih baik ketimbang menerapkan sanksi. Namun, sekali lagi kelakuan atau perbuatan manusia, khususnya terhadap lingkungan hampir tidak dirasakan akibatnya dalam waktu seketika, melainkan bertahun-tahun, bahkan ratusan tahun sesudahnya.Hendaknya para pihak saling menjaga kebersihan lingkungan hidup di sekitarnya karena ini tidak hanya menyangkut kehidupan kita untuk saat ini juga akan tetapi menyangkut kehidupan generasi kita selanjutnya.Tidak sulit untuk menjaga lingkungan di sekitar kita,hal ini tentu saja di mulai dari kesadaran kita sendiri akan pentingnya manfaat lingkungan hidup.

\section{DAFTAR PUSTAKA}

\section{A. Buku-Buku}

Abdurrahman,. Pembaharuan Hukum Acara Pidana Dan Hukum Acara Pidana Baru Di Indonesia,Penerbit Alumni Bandung,1980,Bandung.

Koesnadi Hardjasoemantri,Hukum Tata Lingkungan,Gadjah Mada University Press, Yogyakarta.

Majda El Muhtaj,'Dimensi-Dimensi HAM mengurai hak ekonomi,sosial dan budaya",PT Grafindo Persada,2009.

R.Subekti,Perlindungan hakasasi manusia Dalam KUHAP,PT Pradnya Paramita,Jakarta. 
Tubagus Ronny Rahman Nitibaskara,Ketika Kejahatan Berdaulat,Peradaban ,2001.

B. Jurnal Hukum

Taufiqurrohman S.SH,Pelaksanaan HAM Yang Berkeadilan ,Jurnal Hukum Vol.1 No 2,Agustus 2001

C. Undang-Undang

Undang-undang No. 39Tahun1999 tentang Hak asasi Manusia 